\title{
Increases in humic dissolved organic carbon export from upland peat catchments: the role of temperature, declining sulphur deposition and changes in land management
}

\author{
Adrian R. Yallop*, Ben Clutterbuck, Jonathan Thacker \\ Cranfield University, Cranfield, Bedfordshire, UK
}

\begin{abstract}
Peat soils represent a highly significant carbon store and are usually assumed to serve as net sinks within carbon budgets for climate modelling. However, marked increases in dissolved organic carbon (DOC) concentrations in upland peat drainage waters over the past few decades are widespread in England. This suggests that the assumed sink status of some upland peats could be changing, although, as these observations are seldom quantified into actual carbon flux measurements, their overall importance is difficult to gauge. We investigated the fluvial export of the humic component of DOC (hDOC) from 3 South Pennine catchments and found that the actual carbon export via this pathway has doubled over the last 3 decades. Temperature increases to date appear poorly related to this change. Declining sulphur deposition was more strongly related (inversely), but was not a significant determinant in any of the catchments. The major driver for elevated hDOC export appears to be changes in local land management, namely the extensive use of burning for grouse moor management. Substitution of increased hDOC export into published carbon budget models for upland peat environments imply the study sites have shifted from carbon sinks to net sources over the examined period. This suggests that moorland burning, where undertaken on blanket peat, is incompatible with the ecosystem services these landscapes are presumed to provide and that ideas about the role of upland peat moorland in regional and national carbon cycling need reappraisal.
\end{abstract}

KEY WORDS: Water colour $\cdot$ Humic $\cdot$ DOC $\cdot$ Carbon $\cdot$ Loss $\cdot$ Export $\cdot$ Source $\cdot$ Peatland $\cdot$ Fire Resale or republication not permitted without written consent of the publisher

\section{INTRODUCTION}

Soils contain over twice the mass of carbon held in biomass and atmosphere combined (Batjes 1996), with peat soils representing some $50 \%$ of the UK's soil carbon storage (Milne \& Brown 1997). These organic soils are commonly assumed to act as net sinks for atmospheric carbon dioxide (e.g. Martikainen et al. 1995, Roehm \& Roulet 2003). However, inclusion of fluvial losses in carbon budget estimations suggests that while some UK peatlands may be acting as net carbon sinks (Worrall et al. 2003a), others are at best carbon neutral (e.g. Billett et al. 2004). Changes in the balance of land-atmosphere carbon exchange, in particular those resulting in enhanced soil carbon loss, may be sufficient to affect global warming (Jenkinson et al. 1991), possibly acting as a positive feedback mechanism (Smith \& Shugart 1993, Trumbore et al. 1996, Cox et al. 2000).

The occurrence of such potential changes in carbon budgets may be evidenced by the $91 \%$ increase in mean dissolved organic carbon (DOC) concentrations observed in drainage water from upland peat catchments across the UK over the period 1988-2003 (Evans et al. 2005). DOC is a significant component of fluvial carbon budgets (Meybeck 1993, Pastor et al. 2003, Worrall et al. 2003a, Billett et al. 2004). However, concentration figures alone do not provide data on the 
actual magnitude of fluvial carbon efflux as concentrations are significantly affected by changes in catchment discharge (Grieve 1984, Tranvik \& Jansson 2002). This highlights the importance of carbon flux assessment in investigations of factors presumed to influence soil carbon storage. A number of studies have quantified DOC export in rivers around the globe (see Hope et al. 1994, Dawson \& Smith 2007 for reviews), although very few have examined the actual flux associated with the increasing DOC concentrations observed in the UK. For the year 2002, DOC flux for all UK rivers was estimated to be on the order of $0.86 \mathrm{MtC}$, and

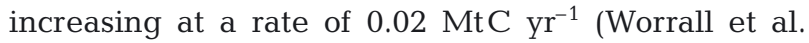
2004). However, determining the origin of DOC in rivers is not straightforward as it arises from a number of sources including (inter alia): decomposition of deep peat if present (McDonald et al. 1991), sewage (e.g. Eatherall et al. 2000), industrial point-source effluents (e.g. Tipping et al. 1997) and products of early stages of plant decomposition (e.g. Palmer et al. 2001). Therefore, the proportion of fluvial carbon flux that can be attributed to potential loss from 'old' deep peat storage is unknown. While the main determinant of DOC export from upland catchments is the proportion of blanket peat they contain (Hope et al. 1997, Aitkenhead et al. 1999), highly significant spatial variation in humic DOC (hDOC) concentration (where DOC is strongly related to levels of organic colour imparted by humic substances; Aiken et al. 1985) is related to differences in land use, namely moorland burning on blanket peat (Yallop et al. 2008, Yallop \& Clutterbuck 2009). Quantification of the actual carbon export that these latter observations represent would provide important information about the relative importance of this land use to the overall fluvial carbon dynamics of upland peat environments and their potential influence on climate.

The aim of the research reported here was therefore to determine any changes in fluvial carbon export from blanket peat over the past few decades and examine the potential influence of meteorological, atmospheric sulphur deposition and land use changes over this time period. Three adjacent South Pennine reservoir catchments were selected for analysis because long-term rainfall and hDOC concentration data (from water utility colour measurements) existed for them. Directly measured stream flow data for the period of recorded DOC data for these catchments were not available. Consequently, runoff was estimated from rainfall by modelling the rainfall-runoff response in gauged catchments with matching physical characteristics (Sefton \& Howarth 1998, Kokkonen et al. 2003).

\section{METHODS}

\subsection{Selection of catchments for runoff modelling}

Flow-gauging locations for all upland areas of England and Wales were sourced from the UK National River Flow Archive (NRFA; www.ceh.ac.uk/data/nrfa). National Soil Resource Institute (NSRI) digital soil data derived from Mackney et al. (1983) were used to exclude those that did not contain areas of blanket peat or raised peat bog (Avery 1980). The remaining subset was then further stratified by removing those where water abstraction or storage occurred above the flow-gauge site. This process resulted in a set of 29 model catchments (Fig. 1), and monthly rainfall and daily flow gauge data for these were obtained from the NRFA. Drainage areas contributing to each of the selected flow-gauge stations were derived using Ordnance Survey PANORAMA 1:50000 digital terrain models (DTMs) and the utilities within ArcHydro GIS tools (Maidment 2002).

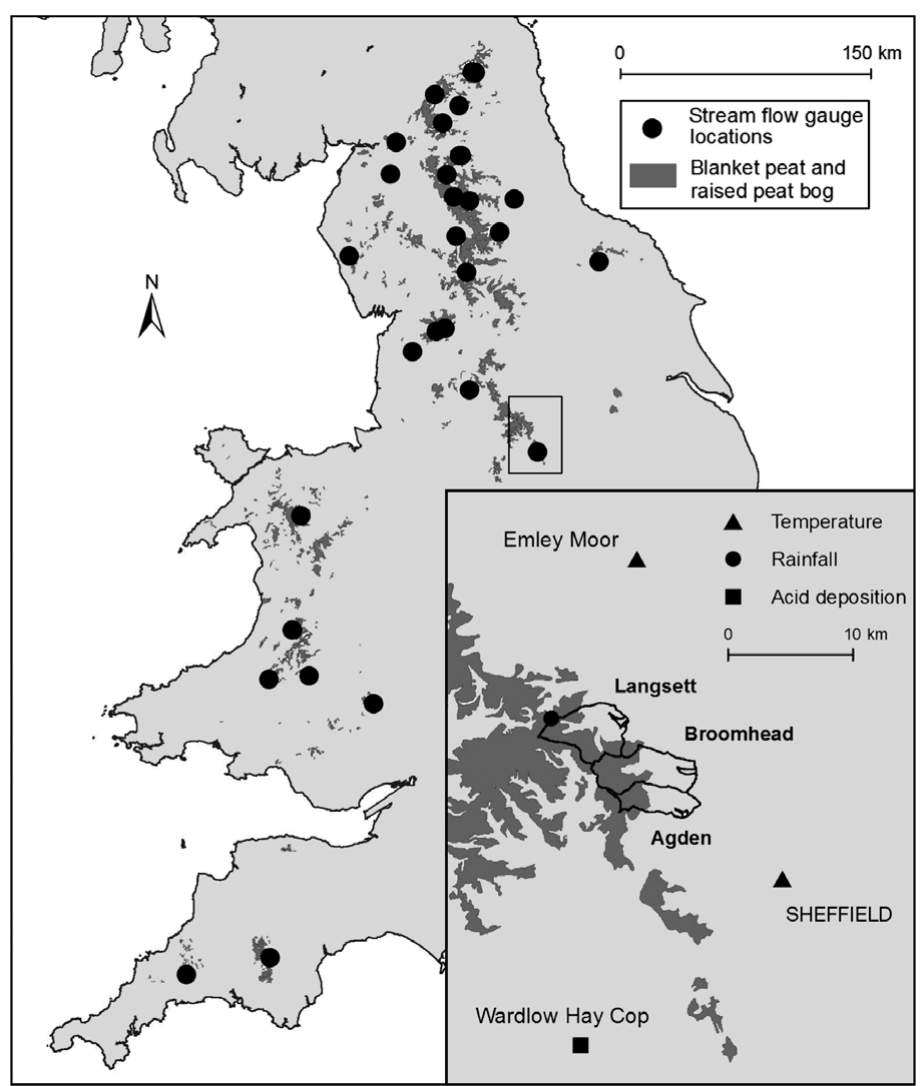

Fig. 1. Location of stream flow gauges monitoring surface waters draining 29 upland peat catchments in the UK selected for runoff modelling. Inset shows the location and extent of the study catchments and position of meteorological and acid deposition monitoring stations 
Table 1. Soil groups present in all catchments categorised by soil type following descriptions given by Avery (1980)

\begin{tabular}{|c|c|c|}
\hline $\begin{array}{l}\text { Blanket peat or } \\
\text { raised peat bog }\end{array}$ & $\begin{array}{l}\text { Upland soils with } \\
\text { peaty topsoils }\end{array}$ & Non-peaty soils \\
\hline Raw peat soils & $\begin{array}{l}\text { Humic rankers } \\
\text { Stagnopodzols } \\
\text { Stagnohumic } \\
\text { gley soils } \\
\text { Humic gley soils }\end{array}$ & $\begin{array}{l}\text { Brown rankers } \\
\text { Non-calcareous } \\
\text { pelosols } \\
\text { Brown earths } \\
\text { Argillic brown earths } \\
\text { Brown podzolic soils } \\
\text { Podzols } \\
\text { Stagnogley soils } \\
\text { Alluvial gley soils } \\
\text { Sandy gley soils }\end{array}$ \\
\hline
\end{tabular}

\subsubsection{Physical catchment descriptors}

Following the methods of Sefton \& Howarth (1998), 4 categories of physical catchment descriptors (PCDs) that influence runoff were derived for each of the 29 model and 3 study catchments: (1) topography: catchment area, mean slope and elevation were derived from DTMs; (2) soil type, categorised into 3 broad soil types: blanket peat and raised peat bog, upland soils with peaty topsoils, and non-peaty soils (Table 1), following the descriptions given by Avery (1980) and identified from NSRI digital soil data; (3) land use/cover: defined by major vegetation type, mapped from year 2000 aerial photography (Table 2); (4) climate: rainfall statistics (1961-1990), were obtained from the NRFA for the 29 model catchments and were estimated for the 3 study catchments using gauged rainfall data for the nearest upland rainfall monitoring station ( $<10 \mathrm{~km}$; Fig. 1) obtained from the British Atmospheric Data Centre (BADC $;$ http://badc.nerc.ac.uk).

\subsubsection{Rainfall-runoff behaviour}

For the 29 model catchments, a runoff:rainfall ratio was calculated for each individual month in the period of data availability. All corresponding monthly ratios for the sampled years were then averaged to deter-

Table 2. Physical catchment descriptors for model and study catchments (soil and land cover variables expressed as percent of catchment). Soil types-BP: blanket peat and raised peat bog; PH: upland soils with peaty topsoils; NP: non-peaty soils. Land cover-CM: Calluna moorland; GM: grass/sedge moorland; IG: improved grass; UG: unimproved grass; PL: plantation; BW: broadleaf woodland

\begin{tabular}{|c|c|c|c|c|c|c|c|c|c|c|c|c|c|c|}
\hline \multirow[t]{2}{*}{ Catchment } & \multirow[t]{2}{*}{ Location } & \multicolumn{4}{|c|}{ Catchment characteristics -} & \multicolumn{3}{|c|}{ — Soil type- } & \multicolumn{6}{|c|}{ Land cover } \\
\hline & & $\begin{array}{l}\text { Area } \\
\left(\mathrm{km}^{2}\right)\end{array}$ & $\begin{array}{c}\text { Slope } \\
\left({ }^{\circ}\right)\end{array}$ & $\begin{array}{l}\text { Annual rain- } \\
\text { fall (mm) }\end{array}$ & $\begin{array}{l}\text { Altitude } \\
\text { (m) }\end{array}$ & BP & $\mathrm{PH}$ & NP & $\mathrm{CM}$ & GM & IG & UG & PL & BW \\
\hline Bedburn Beck & N Pennines & 75 & 5.8 & 894 & 316 & 15 & 46 & 39 & 44 & 6 & 16 & 1 & 32 & 1 \\
\hline Brock & N Pennines & 35 & 5.7 & 1360 & 185 & 5 & 28 & 67 & 4 & 10 & 76 & 0 & 1 & 8 \\
\hline Burbage Brook & S Pennines & 8 & 4.7 & 1004 & 385 & 35 & 39 & 26 & 56 & 15 & 3 & 19 & 4 & 2 \\
\hline Caldew & Cumbria & 150 & 7.4 & 1399 & 322 & 14 & 71 & 15 & 5 & 24 & 50 & 15 & 4 & 1 \\
\hline Coal Burn & N Pennines & 2 & 2.5 & 1096 & 305 & 88 & 0 & 12 & 0 & 0 & 0 & 0 & 100 & 0 \\
\hline Coquet & N Pennines & 60 & 11.1 & 1020 & 407 & 20 & 56 & 25 & 7 & 40 & 0 & 48 & 6 & 0 \\
\hline Ding Brook & S Pennines & 2 & 7.3 & 1489 & 416 & 58 & 42 & 0 & 0 & 0 & 100 & 0 & 0 & 0 \\
\hline Dunsop & N Pennines & 25 & 10.1 & 1915 & 364 & 66 & 0 & 34 & 50 & 43 & 5 & 0 & 2 & 0 \\
\hline East Allen & N Pennines & 89 & 5.8 & 900 & 385 & 16 & 53 & 30 & 28 & 15 & 52 & 3 & 1 & 1 \\
\hline East Dart & Dartmoor & 22 & 5.2 & 2088 & 459 & 44 & 15 & 41 & 3 & 76 & 7 & 9 & 5 & 0 \\
\hline Eden & N Pennines & 68 & 8.3 & 1483 & 391 & 30 & 38 & 33 & 4 & 55 & 31 & 9 & 0 & 1 \\
\hline Esk & Cumbria & 70 & 12.7 & 2305 & 314 & 10 & 39 & 51 & 0 & 60 & 9 & 26 & 1 & 4 \\
\hline Gelyn & North Wales & 13 & 7.2 & 2008 & 423 & 35 & 2 & 63 & 16 & 82 & 0 & 2 & 0 & 0 \\
\hline Greta & N Pennines & 87 & 3.4 & 1128 & 403 & 67 & 17 & 16 & 54 & 24 & 21 & 1 & 0 & 0 \\
\hline Hodge Beck & N York Moors & 19 & 8.8 & 987 & 323 & 20 & 45 & 36 & 49 & 2 & 28 & 5 & 13 & 2 \\
\hline Honddu & Brecon Beacons & 25 & 14.1 & 1313 & 521 & 15 & 52 & 33 & 12 & 37 & 19 & 31 & 2 & 0 \\
\hline Irfon & Cambrian Mtns & 73 & 10.4 & 1842 & 412 & 26 & 42 & 32 & 0 & 28 & 14 & 14 & 43 & 0 \\
\hline Kielder Burn & N Pennines & 59 & 7.7 & 1199 & 408 & 56 & 5 & 39 & 27 & 37 & 0 & 4 & 32 & 0 \\
\hline Landon Beck & N Pennines & 13 & 6.7 & 1462 & 543 & 78 & 8 & 15 & 14 & 78 & 5 & 3 & 0 & 0 \\
\hline Lyne & N Pennines & 213 & 3.8 & 1136 & 170 & 15 & 44 & 41 & 1 & 10 & 61 & 0 & 28 & 0 \\
\hline Snaizeholme & N Pennines & 11 & 10.8 & 1734 & 445 & 17 & 11 & 72 & 0 & 80 & 0 & 9 & 11 & 0 \\
\hline South Tyne & N Pennines & 119 & 6.6 & 1523 & 513 & 62 & 24 & 14 & 26 & 48 & 12 & 12 & 2 & 0 \\
\hline Tarset Burn & N Pennines & 96 & 4.6 & 994 & 300 & 19 & 7 & 73 & 19 & 33 & 3 & 2 & 43 & 0 \\
\hline Trout Beck & N Pennines & 12 & 5 & 1902 & 656 & 97 & 0 & 3 & 40 & 60 & 0 & 0 & 0 & 0 \\
\hline Twrch & Cambrian Mtns & 21 & 8.6 & 1533 & 311 & 3 & 63 & 34 & 0 & 26 & 55 & 11 & 8 & 0 \\
\hline Usway Burn & N Pennines & 22 & 11.2 & 1056 & 445 & 53 & 29 & 18 & 16 & 23 & 0 & 22 & 39 & 0 \\
\hline Warleggan & Bodmin Moor & 25 & 5.1 & 1442 & 219 & 11 & 49 & 40 & 0 & 41 & 48 & 5 & 0 & 6 \\
\hline West Allen & N Pennines & 80 & 6.6 & 1155 & 401 & 33 & 32 & 34 & 20 & 45 & 26 & 6 & 1 & 3 \\
\hline Ystwyth & Cambrian Mtns & 32 & 10.2 & 1994 & 455 & 42 & 24 & 34 & 3 & 45 & 2 & 22 & 28 & 0 \\
\hline Agden & S Pennines & 12 & 8.4 & 1493 & 355 & 34 & 56 & 8 & 50 & 24 & 11 & 2 & 5 & 6 \\
\hline Broomhead & S Pennines & 21 & 8.5 & 1493 & 363 & 42 & 14 & 41 & 53 & 13 & 15 & 2 & 8 & 6 \\
\hline Langsett & S Pennines & 21 & 7.3 & 1493 & 394 & 51 & 6 & 40 & 57 & 27 & 7 & 0 & 7 & 0 \\
\hline
\end{tabular}


mine a mean monthly runoff ratio (i.e. 12 per catchment). Monthly rainfall was multiplied by catchment area to determine monthly rainfall volume. Daily mean stream flow rates $\left(\mathrm{m}^{3} \mathrm{~s}^{-1}\right)$ were converted to daily volumes and summed to produce cumulative monthly runoff. An annual mean runoff ratio was also derived for each catchment.

\subsection{Determination of catchments with comparable runoff}

\subsubsection{Principal component analysis}

A principal component analysis (PCA) was used to identify catchments with comparable PCDs (performed in Canoco Version 4.5). All PCDs were entered into the PCA and were standardised during analysis. For each of the 3 study catchments, the 3 'closest' model catchments (defined by Euclidean distance in ordination space) were selected. Euclidean distance was calculated from the coordinates of each catchment in principal components 1 (PC1) and 2 (PC2). This identified a total of 7 predictor catchments (Fig. 2) to be used for runoff estimation. For each of the study catchments, mean monthly runoff ratios were then estimated by applying an inverse distance weighted (IDW) algorithm (Shepard 1968) to the mean monthly ratios calculated for the 3 closest predictor catchments identified by PCA.

\subsubsection{Qualitative assessment of model performance}

In total, PC1 and PC2 explained nearly $50 \%$ of the covariance in the PCD variables entered into analysis (Fig. 2). Three catchments containing significantly higher cover of blanket peat (97\%: Trout Beck), plantation (100\%: Coal Burn) and improved grassland (100\%: Ding Brook) were located discretely from other catchments in ordination space. The annual runoff ratios of the remaining 26 model catchments showed

Table 3. Seven predictor catchments used to estimate runoff for study catchments. N, S: North, South Pennines, respectively; IDW: inverse distance weighting; BH: Broomhead; AG: Agden; LS: Langsett

\begin{tabular}{|lcccc|}
\hline $\begin{array}{l}\text { River flow gauge/ } \\
\text { catchment }\end{array}$ & Location & $\begin{array}{c}\text { Data availability } \\
\text { (no. complete months) }\end{array}$ & $\begin{array}{c}\text { Annual runoff } \\
\text { ratio (SE) }\end{array}$ & $\begin{array}{c}\text { Study catchment } \\
\text { (IDW applied) }\end{array}$ \\
\hline Burbage Brook & N & Jan 1965-Dec 1982 (172) & $0.65(0.05)$ & BH (0.14) \\
Eden & N & Oct 1971-Dec 2007 (404) & $0.82(0.01)$ & AG (0.17) \\
Kielder Burn & N & Jul 1970-Dec 2006 (415) & $0.81(0.01)$ & LS (0.55) \\
South Tyne & N & Oct 1969-Dec 1998 (218) & $0.76(0.02)$ & LS (0.06) \\
Tarset Burn & S & Jul 1970-Jun 1980 (120) & $0.62(0.03)$ & AG (0.30), BH (0.57) \\
Usway Burn & N & Oct 1970-Jun 1980 (270) & $0.76(0.03)$ & LS (0.39) \\
West Allen & N & Jun 1971-Dec 1980 (115) & $0.63(0.03)$ & AG (0.53), BH (0.29) \\
\hline
\end{tabular}

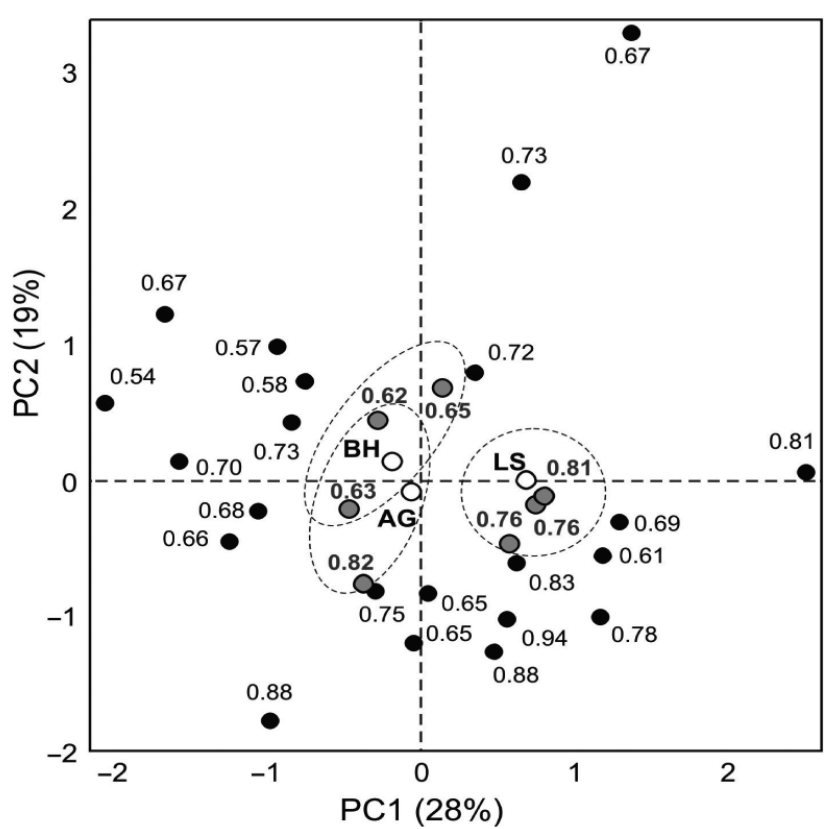

Fig. 2. Principal component analysis of physical catchment descriptors of 29 model upland peat catchments for which runoff data were available $(\bullet)$ and the 3 study catchments $\left(O_{\text {; }}\right.$ AG: Agden; BH: Broomhead; LS: Langsett). Numbers: annual mean runoff ratio; dotted lines: closest model catchments identified by Euclidean distance (o) used to model runoff in the study catchments and for model validation

an apparent increasing trend with PC1 and decreasing trend with PC2. All 7 predictor catchments identified by PCA are located in the North or South Pennines, as are the study catchments (Table 3); this is of particular note as no geographical location factor was entered in PCA and suggests good commonality in catchment characteristics in this region and, presumably, runoff behaviour.

Seasonal variation is evident in the monthly runoff ratios determined for each selected predictor catchment (Fig. 3), with a higher proportion of rainfall leaving as runoff between January and March. For 2 of the study catchments, the 3 predictor catchments selected to model runoff had comparable annual and monthly runoff ratios: Broomhead (0.62 to 0.65) and Langsett (0.76 to 0.81 ; Fig. 3 ). For the Agden catchment, one of the catchments selected to model runoff exhibited a significantly higher annual runoff ratio (0.82) compared to the closest 2 catchments (0.62 to 0.63). However, in the model design implemented here, this catchment contributed only $17 \%$ of the overall runoff model (Table 3). 


\subsection{Runoff model validation}

As stream-flow data for the 3 study catchments were not available, direct validation of modelled runoff volume for these catchments was not possible. The error associated with predicting a mean monthly runoff ratio was therefore assessed by selecting the 7 catchments used to model run-off and treating them as un-gauged catchments. Thus, the 3 nearest model catchments in ordination space to each of the 7 predictor catchments were used to model those catchments' flows, and these estimates were then compared to known values. Mean runoff ratio error was determined by calculating the standard error of the differences between modelled and actual monthly stream flow ratios.
The accuracy of predictions (difference between estimated and observed flow ratio) for each month for the 7 cross-validation catchments ranged from -0.23 to +0.33 (mean $=+0.04$ ), but the overall performance of the models on an annual basis was more consistent, predicting flow ratios to within a range of -0.03 to +0.11 (mean prediction 0.04 above measured flow ratio, $\mathrm{SE}=0.02$ ). The $95 \%$ confidence intervals $( \pm 2 \mathrm{SE}$ ) of the monthly predictions had a mean range of $0.18(-0.12$ to +0.05 , i.e. 88 to $105 \%$ of true values). Owing to chance effects, the models for the 7 cross-validation catchments tended to slightly overestimate flow ratios, which is reflected in the distribution of confidence intervals. The monthly confidence intervals in flow-rate prediction were applied to modelled flow rates in the studied catchments to give upper and lower bounds for estimated flows.

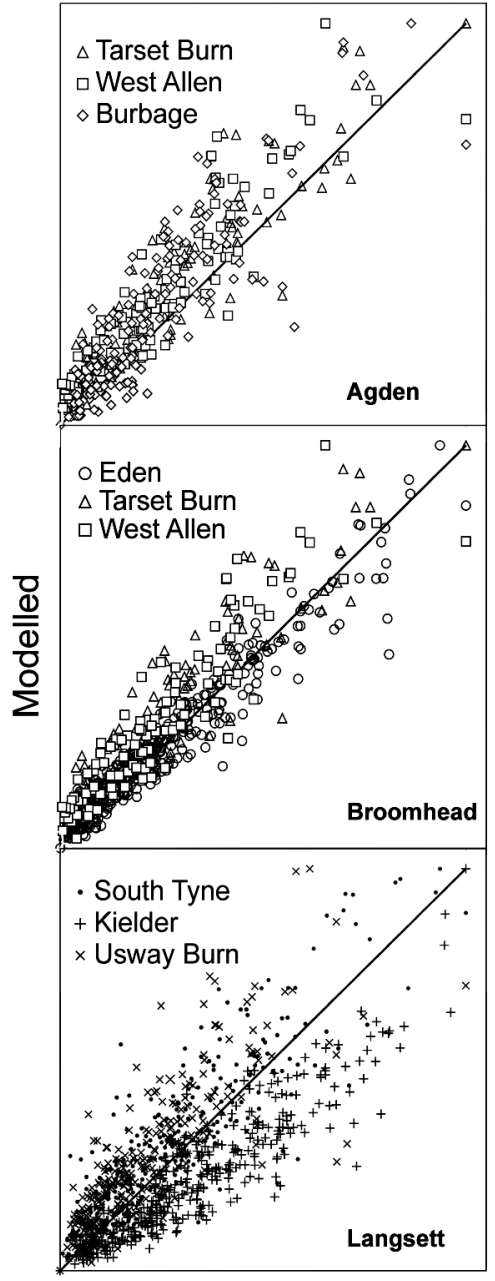

Observed
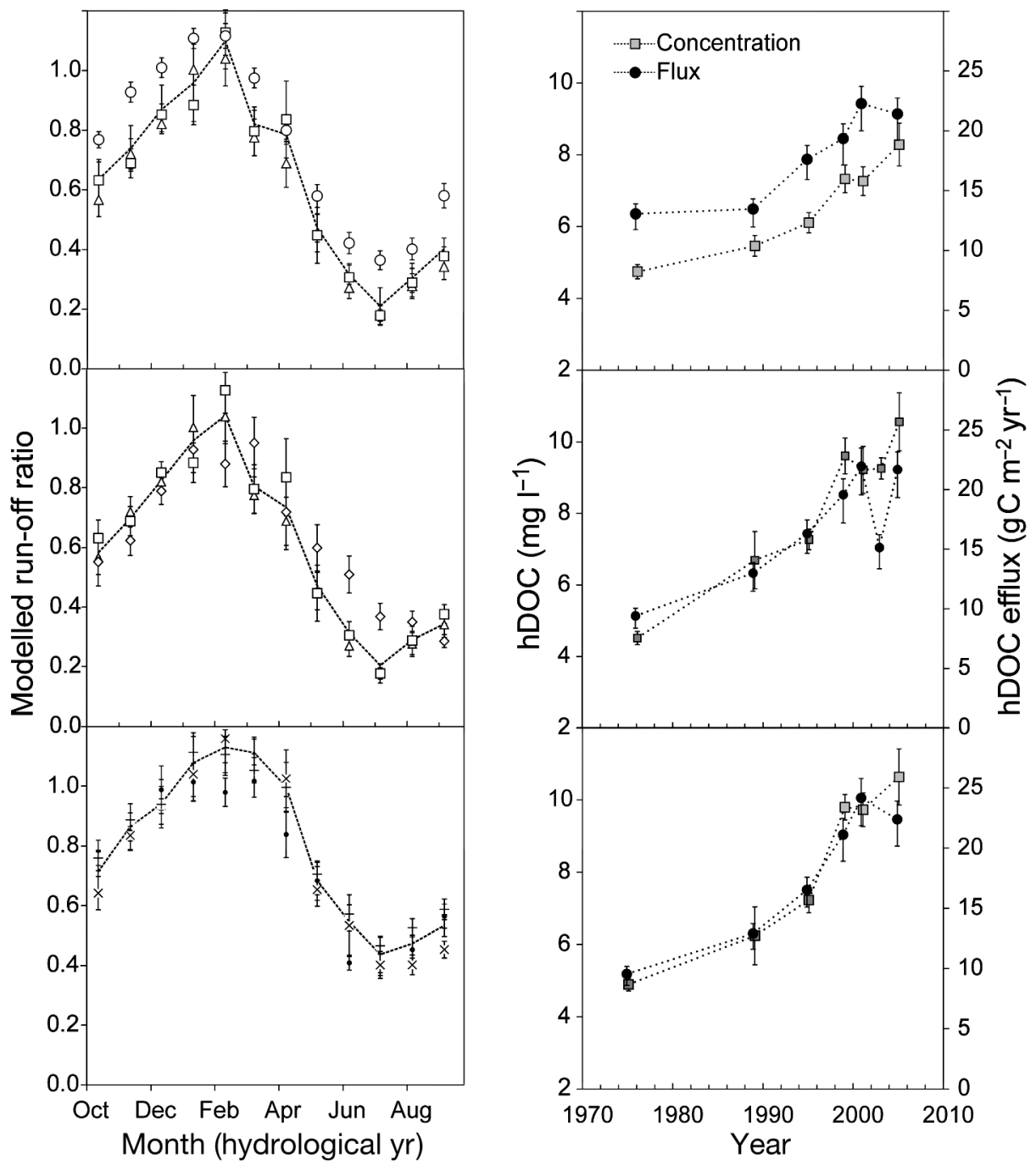

Fig. 3. Inverse distance weighted (IDW) runoff and humic dissolved organic carbon (hDOC) export modelling. Left: modelled runoff compared to actual for the 3 predictor catchments used for the named catchment (1:1 line shown). Centre: monthly runoff ratio for model catchments. The IDW runoff ratio line is shown relative to the 3 predictor catchments. Right: hDOC concentrations (left axis) and modelled efflux (right axis) for period 1976-2005 


\subsection{Determination of DOC flux}

\subsubsection{Determination of $\mathrm{hDOC}$ concentration}

Estimation of DOC concentration from water colour determined as Hazen has been used in several previous studies (e.g. Kerekes et al. 1986, Eatherall et al. 1998, Worrall et al. 2003b), and this approach was adopted here. This method is based on standardised absorption and produces estimates of humic coloured DOC. It does not, therefore, provide evidence of the concentrations of other sources or fluxes of colourless DOC. Although these will be relatively small in waters draining blanket peat catchments, to avoid potential misinterpretation, the term hDOC is used henceforth to differentiate the origin of the data used, and effectively the component of DOC assessed. The relationship between hDOC concentration $\left(\mathrm{mg} \mathrm{l}^{-1}\right.$ ) and Hazen was derived from regression of these 2 parameters determined in 181 water samples collected within the study catchments during 2005 (see Yallop \& Clutterbuck 2009):

$$
\begin{gathered}
\text { hDOC concentration }=0.044 \times \text { Hazen }+3.89 \\
\left(\mathrm{r}^{2}=0.93, \mathrm{p}<0.001\right)
\end{gathered}
$$

Mean monthly colour as Hazen was calculated for each catchment for all years of data availability from 1975 to 2005, and subsequently converted to DOC using the above function (Eq. 1). For the period March 1979 to December 1989, colour data were recorded as UV absorbance (measured at $400 \mathrm{~nm}, A_{400}$ ), and therefore mean absorbance values were firstly converted to Hazen using the relationship between absorbance and Hazen determined for water sampled from Broomhead by Watts et al. (2001):

$$
\text { Hazen }=11.77 \times A_{400}
$$

Prior to 1984, colour was determined in unfiltered water (apparent colour) and would therefore contain some particulate organic carbon (POC). To determine true colour, correction for the particulate component was performed using the relationship between true and apparent absorbance determined for water sampled from Broomhead by Watts et al. (2001), prior to determination of Hazen:

$$
A_{\mathrm{T}}=1.06+\left(0.63 \times A_{\mathrm{A}}\right)
$$

where $A_{\mathrm{T}}$ and $A_{\mathrm{A}}$ are true and apparent absorbance, respectively.

\subsubsection{Determination of standard errors for estimated hDOC concentration}

In most cases only a single measure of $\mathrm{hDOC}$ was available for each studied catchment for each month.
For this reason, standard errors could not be calculated in the normal way. However, it was possible to use the consistent annual pattern in hDOC levels at each site to generate standard errors based on deviations from that pattern. In general, hDOC levels were highest in the winter and lowest in summer, irrespective of overall levels. A standardised expected hDOC pattern was generated for each studied catchment by dividing monthly observations of hDOC by the mean level for the relevant calendar year. Standard errors were calculated from variability in the standardised hDOC pattern between years, and were then multiplied by observed hDOC concentrations in each month to provide scaled standard errors, which were then used to calculate confidence limits $( \pm 2 \mathrm{SE})$. The confidence limits produced in this way scale linearly with hDOC. They are quite conservative, with 2 standard errors equating to a difference in monthly hDOC of \pm 5 to $6 \%$.

\subsection{3. hDOC flux estimation}

For each study catchment, monthly rainfall volumes were estimated from rainfall data (from the BADC), multiplied by catchment area, for the period during which hDOC concentration data were available. Runoff volume was then estimated by multiplying rainfall volume by the mean monthly runoff ratio estimated for that catchment. Monthly hDOC flux was then calculated as the product of mean monthly hDOC concentration and monthly runoff volume, following the method in Buckingham et al. (2008). Annual (calendar year) hDOC flux was estimated from the sum of monthly values, and was then scaled by the amount of blanket peat within each catchment (the primary source of hDOC; McDonald et al. 1991) to derive fluvial carbon export per square metre of blanket peat. Trends in hDOC export were identified using the Seasonal Kendall test (Hirsch et al. 1982). Owing to the possible increased error associated with the use of early 1980s absorbance data, trend analysis was performed for the period 1990-2005.

\subsection{Identification of possible determinants of hDOC flux}

\subsubsection{Temperature}

The nearest temperature record for Agden, Broomhead and Langsett catchments (1975-2006) is at Sheffield (15 km east; Fig. 1). Recorded temperatures in Sheffield are potentially higher than those occurring in the studied catchments as a consequence of both lower altitude and urban heat island effects (e.g. Oke 
1982). The potential consequences of this were reduced by using a shorter-term data set (1984-2005) from Emley Moor (15 km north of the study site in a moorland environment). The relationship between mean monthly temperatures at the 2 monitoring stations was identified by linear regression:

$$
T_{\mathrm{E}}=\left(0.975 \times T_{\mathrm{S}}\right)-0.964 \quad\left(\mathrm{r}^{2}=0.99, \mathrm{p}<0.001\right)
$$

where $T_{\mathrm{E}}$ is mean monthly temperature $\left({ }^{\circ} \mathrm{C}\right)$ at Emley Moor and $T_{\mathrm{S}}$ is mean monthly temperature at Sheffield. This relationship was then used to correct Sheffield data for the missing period at Emley Moor (1975-1984).

Daily mean temperatures for each monitoring station were calculated as the average of daily minima and maxima (Holden \& Adamson 2002). Monthly and annual mean temperatures were derived from these daily means.

\subsubsection{Acid deposition data}

Wet-deposition sulphate data for the study catchments were sourced from the UK Air Quality Archive for Wardlow Hay Cop monitoring station, which is located less than $20 \mathrm{~km}$ to the south of this catchment group (www.airquality.co.uk). Monthly and annual total deposition $\left(\mathrm{mg} \mathrm{m}^{-2}\right)$ of non-marine sulphate $\left(\mathrm{xSO}_{4}{ }^{2-}\right)$, the pollutant fraction, were determined for the period of data availability (1986-2005).

\subsubsection{Determination of land use changes}

Aerial imagery for 1976, 1989, 1995, 2001, 2003 and 2005 were scanned, and ortho-corrected mosaics were then created. Land cover classes consistently identifiable across the catchments (see Table 2) were digitised for each year of photographic capture. Grouse moor burn management is common in all 3 catchments and this was also mapped using the method described in Yallop \& Clutterbuck (2009), which defines 4 classes of burn scar: Class 1, no visible Calluna regeneration since burning; Class 2, some regrowth but with only a partial canopy; and Classes 3 \& 4, young and older stands of closed canopy heather, respectively. Artificial drainage was visible in a small area of Langsett catchment, but the extent did not change between years of image availability.

The areal extent of all combinations of land cover, management and soil type present (derived from NSRI digital soil data) in each catchment by year were derived within a GIS. The proportion of blanket peat covered by each land cover class by year was then calculated, and normalised prior to analysis using the arcsin-square root transformation (Fowler \& Cohen 1990).

\subsubsection{Statistical analysis}

The primary source of hDOC from upland catchments derives from the decomposition of blanket peat (McDonald et al. 1991). Therefore, relationships between annual hDOC flux (scaled by the area of blanket peat) and (1) land use and/or management on blanket peat; (2) sulphur deposition; and (3) temperature for the years of image availability were examined for the period 1989-2005. To look for possible interactions between these factors, an initial analysis was undertaken using forward-entry stepwise multiple regression, with condition for entry set as improvements in the model at $\mathrm{p}<$ 0.05. Following this, additional individual regressions were conducted on any factors not selected in the original regression model to elucidate their individual relationship to hDOC efflux. These steps were repeated with the addition of land use, temperature and hDOC flux data from 1976. Analysis was performed initially using data for all catchments pooled to increase the number of observations. Any relationships identified were then examined within individual catchments.

To quantify the effect of changes in the extent of land use on carbon export from blanket peat, the combined area of blanket peat located within Agden, Langsett and Broomhead catchments $\left(24 \mathrm{~km}^{2}\right)$ was assessed for the period 1976-2005. The area of the land use factors identified in the analyses above were summed by year for the full extent of blanket peat and entered into a linear regression against total carbon efflux determined from the $24 \mathrm{~km}^{2}$ of blanket peat for each year of data availability.

\section{RESULTS}

\subsection{Trends in hDOC efflux}

For the period 1990-2005, estimated hDOC efflux shows strong overall concordance with the trend in concentration for each of the study catchments (Fig. 3). A highly significant increasing trend in hDOC efflux $(p<0.001)$ was identified for this period, ranging from 0.31 to $0.55 \mathrm{~g} \mathrm{~m}^{-2} \mathrm{yr}^{-1}$ (1.28 to $5.94 \times 10^{6} \mathrm{~g} \mathrm{yr}^{-1}$ ). Over the longer period, estimated fluvial humic carbon export ranged from $9.4-11.8 \mathrm{~g} \mathrm{~m}^{-2} \mathrm{yr}^{-1}$ in 1976 to 27.7-29.3 $\mathrm{g} \mathrm{m}^{-2} \mathrm{yr}^{-1}$ in 2000 (Table 4).

\subsection{Relationships between tested factors and hDOC efflux}

\subsubsection{Pooled catchment data}

Of the temperature, sulphate deposition and land use and/or management factors tested in forward- 
entry multiple regression (1989-2005), the proportion of new burn on blanket peat burned (Class 1) was identified as the most significant factor relating to hDOC efflux from blanket peat $\left(\mathrm{r}^{2}=0.39, \mathrm{p}=0.009\right.$; Fig. 4a). Annual temperature was added to the regression, improving the model fit to $\mathrm{r}^{2}=0.59(\mathrm{p}=$ 0.003 ; Table 5). Individual regression of $\mathrm{xSO}_{4}{ }^{2-}$ deposition identified a less significant inverse relationship with hDOC efflux $\left(\mathrm{r}^{2}=0.20, \mathrm{p}=0.05\right.$; Fig. $\left.4 \mathrm{~b}\right)$. Inclusion of data for 1976 identified a stronger relationship between the proportion new burn on blanket peat and $\mathrm{hDOC}$ efflux from blanket peat $\left(\mathrm{r}^{2}=0.58, \mathrm{p}<\right.$ 0.001; Fig. 4a), but no interaction with temperature (Table 5).

\subsubsection{Individual catchments}

In each individual catchment, the proportion of new burn on blanket peat (Class 1) was the only factor chosen by the analysis as significantly related to $\mathrm{hDOC}$ export, with $\mathrm{r}^{2}=0.68$ to 0.79 (Fig. $5 \mathrm{a}-\mathrm{C}$ ). No significant relationships were identified in individual regressions of $\mathrm{xSO}_{4}{ }^{2-}$ deposition or temperature (Table 5).

\subsubsection{Effect of burning on hDOC efflux}

For the combined 3 catchments, hDOC efflux $\left(10^{6} \mathrm{gC}\right)$ was estimated by:

hDOC efflux $=$

$((70.1 \pm 19.9 \times$ area of Class 1 burn $)+229.1 \pm 61.1)$

where the area of Class 1 burn is in $\mathrm{km}^{2}\left(\mathrm{r}^{2}=0.69\right.$, $\mathrm{p}=0.025$, SE of coefficients shown). This function (Eq. 5), derived from regression of the area of new burn on blanket peat against annual hDOC efflux (Fig. 6) for the combined area of blanket peat located in the Agden, Broomhead and Langsett catchments $\left(24 \mathrm{~km}^{2}\right)$, indicates that background $\mathrm{hDOC}$ export from blanket peat in the South Pennines (i.e. with no controlled burning) averages $9.5 \pm 2.5 \mathrm{~g} \mathrm{~m}^{-2} \mathrm{yr}^{-1}$. Areas of newly burnt blanket peat are responsible

Table 4. Trends in humic dissolved organic carbon efflux identified by the Seasonal Kendall test and estimated rates of carbon export from blanket peat by study catchment. ${ }^{* * *} \mathrm{p}<0.001$

\begin{tabular}{|llcc|}
\hline \multirow{2}{*}{ Catchment } & \multicolumn{2}{c}{ Trend } & Range \\
\cline { 2 - 3 } & $\left(10^{6} \mathrm{~g} \mathrm{yr}^{-1}\right)$ & $\left(\mathrm{g} \mathrm{m}^{-2} \mathrm{yr}^{-1}\right)$ & $\left(\mathrm{g} \mathrm{m}^{-2} \mathrm{yr}^{-1}\right)$ \\
\hline Agden & $+1.28^{* * *}$ & +0.31 & $11.8-28.3$ \\
Broomhead & $+3.61^{* * *}$ & +0.40 & $9.4-27.7$ \\
Langsett & $+5.94^{* * *}$ & +0.55 & $9.5-29.3$ \\
\hline
\end{tabular}

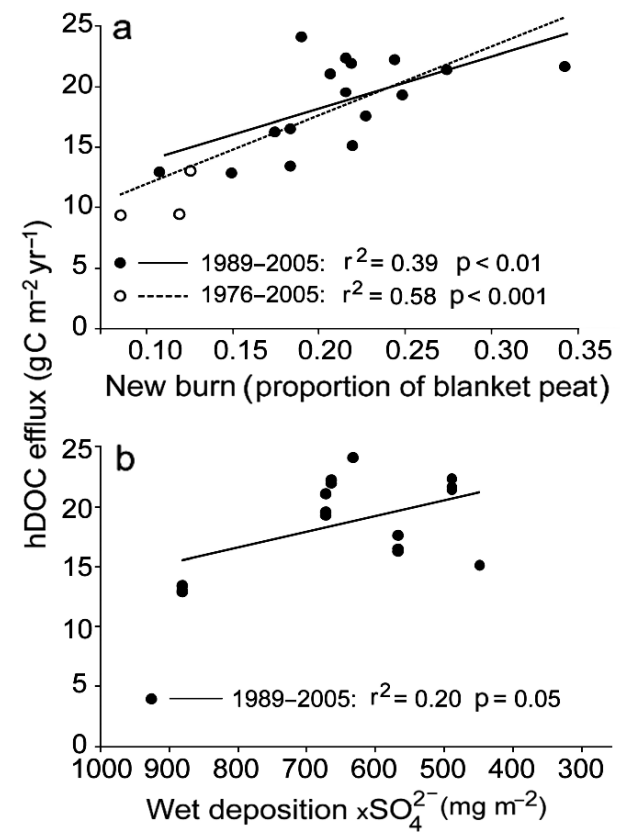

Fig. 4. Relationship between annual humic dissolved organic carbon (hDOC) efflux and (a) Class 1 burn on blanket peat and (b) $\mathrm{xSO}_{4}{ }^{2-}$ wet deposition. Data are pooled for all 3 catchments. Note that 2 time series are shown in (a): 1976-2005 and the period 1989-2005, for which sulphur deposition data were available

for 5 to 15 times as much hDOC efflux: $79.6 \pm 22.4 \mathrm{~g}$ $\mathrm{m}^{-2} \mathrm{yr}^{-1}$. The absolute values given should be interpreted with caution, but relative differences are consistent and independent of modelling error.

\section{DISCUSSION}

The use of monthly rainfall modelling has allowed seasonal variation in runoff generation and $\mathrm{hDOC}$ production to be accounted (Fig. 3). This has produced estimated runoff ratios comparable to other upland peat catchments in the UK (Dawson et al. 2008) and accurately modelled annual mean flow. However, the model would not account for dry antecedent conditions, and in such circumstances predictions may overestimate runoff. DOC supply to drainage is also influenced by changes in precipitation and runoff (Grieve 1984, Tranvik \& Jansson 2002), so there is also an inherent degree of circularity in using rainfall and DOC concentration to determine DOC flux. Low runoff volumes will also export less total carbon for given DOC concentrations; however, reduced DOC productivity may also occur during drought conditions (e.g. Scott et al. 1998). Therefore, generalisations inherent in the modelling mean that the absolute values predicted for hDOC export need to be interpreted with 
Table 5. Relationships between land management and humic dissolved organic carbon (hDOC) export from blanket peat (Class 1 burn), temperature and sulphate deposition $\left(\mathrm{xSO}_{4}{ }^{2}\right.$, which shows an inverse relationship to hDOC flux) in examined catchments. FE multiple: forward-entry multiple regression; single linear: the factor was not selected by the forward-entry multiple regression analysis conducted on all factors and therefore a single linear regression was performed for this factor separately

\begin{tabular}{|c|c|c|c|c|c|c|c|}
\hline Catchment & Regression type & 1st variable & $\mathrm{r}^{2}$ & $\mathrm{p}$ & 2nd variable & $r^{2}$ & $\mathrm{p}$ \\
\hline \multicolumn{8}{|l|}{ All } \\
\hline \multirow[t]{3}{*}{ 1989-2005 } & FE multiple & Class 1 burn & 0.39 & 0.009 & \multirow[t]{3}{*}{ Temperature } & \multirow[t]{3}{*}{0.59} & \multirow[t]{3}{*}{0.003} \\
\hline & Single linear & Temperature & 0.02 & 0.283 & & & \\
\hline & Single linear & $\mathrm{xSO}_{4}^{2-}$ & 0.20 & 0.050 & & & \\
\hline \multirow[t]{2}{*}{ 1976-2005 } & FE multiple & Class 1 burn & 0.58 & $<0.001$ & \multirow[t]{2}{*}{ None } & & \\
\hline & Single linear & Temperature & 0.02 & 0.267 & & & \\
\hline \multirow[t]{3}{*}{ Agden } & FE multiple & Class 1 burn & 0.79 & 0.011 & \multirow[t]{3}{*}{ None } & & \\
\hline & Single linear & Temperature & 0.08 & 0.591 & & & \\
\hline & Single linear & $\mathrm{xSO}_{4}^{2-}$ & 0.36 & 0.166 & & & \\
\hline \multirow[t]{3}{*}{ Broomhead } & FE multiple & Class 1 burn & 0.68 & 0.014 & \multirow[t]{3}{*}{ None } & & \\
\hline & Single linear & Temperature & 0.06 & 0.608 & & & \\
\hline & Single linear & $\mathrm{xSO}_{4}^{2-}$ & 0.11 & 0.522 & & & \\
\hline \multirow[t]{3}{*}{ Langsett } & FE multiple & Class 1 burn & 0.79 & 0.011 & \multirow[t]{3}{*}{ None } & & \\
\hline & Single linear & Temperature & 0.13 & 0.475 & & & \\
\hline & Single linear & $\mathrm{xSO}_{4}^{2-}$ & 0.15 & 0.280 & & & \\
\hline
\end{tabular}
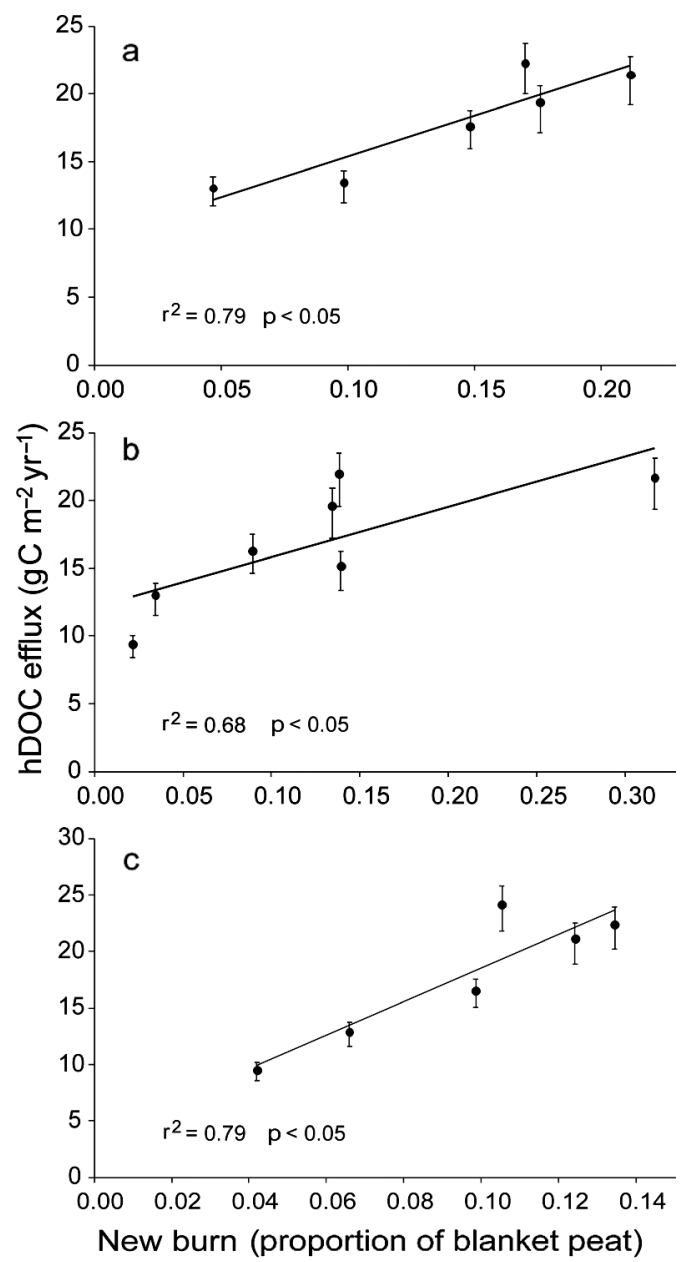

Fig. 5. Relationship between Class 1 burn on blanket peat and annual humic dissolved organic carbon (hDOC) efflux in the

(a) Agden, (b) Broomhead and (c) Langsett catchments caution, although as none of the errors exhibit trends through time (flow ratios in the models are the same for each year and hDOC confidence intervals scale with hDOC; the only possibility of systematic bias in flux would be if rainfall, and therefore flow, was itself trended, which it is not), they could not lead to false identification of relative trends. This indicates that the rising hDOC concentrations observed in these catchments (and by implication in many other upland blanket peat catchments, where increased DOC concentrations have been observed: e.g. Evans et al. 2005) represent real changes in fluvial carbon export, as suggested by Worrall et al. (2003b).

A strong relationship was present between the proportion of new burn (Class 1) on blanket peat and hDOC efflux in the 3 studied catchments $\left(\mathrm{r}^{2}=0.58\right.$ where the data were grouped and $r^{2}=0.68$ to 0.79 when examined separately). It is clear that the highly significant relationship between new burn extent on

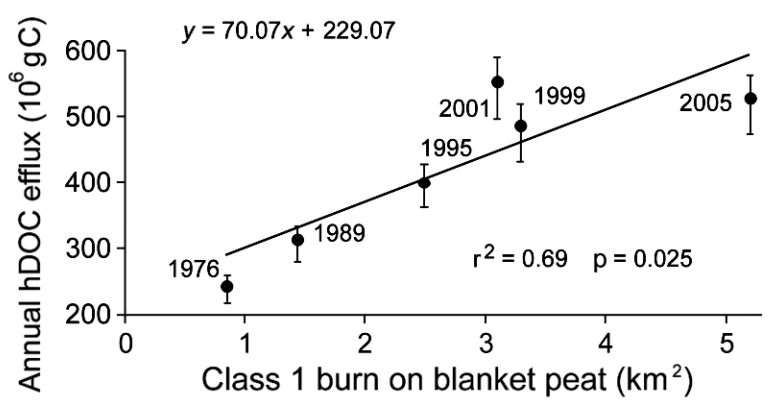

Fig. 6. Relationship between Class 1 burn on blanket peat against export of humic dissolved organic carbon (hDOC) from blanket peat $\left(24 \mathrm{~km}^{2}\right)$ located in the Agden, Broomhead and Langsett catchments 
blanket peat and both spatial (Yallop et al. 2008, Yallop \& Clutterbuck 2009), and temporal variation (Clutterbuck \& Yallop in press), in drainage DOC concentrations translates into increased fluvial carbon export from catchments managed in this way. The weaker inverse relationship observed between non-marine sulphate deposition and hDOC efflux when the catchment data were grouped was not significant in catchments examined individually. It is possible this occurs due to the sulphur deposition data being sourced from a monitoring site $20 \mathrm{~km}$ from the 3 study sites, or as a consequence of reduced degrees of freedom in the analysis. If sulphur deposition, however, is relatively homogenous at this scale, it would indicate that localised land management, in this case the increase in burn management on blanket peat, has a greater influence over $\mathrm{hDOC}$ export than regional-scale factors such as atmospheric deposition. This would agree with observations (Clutterbuck \& Yallop in press) that, although long-term changes in sulphur deposition and temperature may explain 20 to $30 \%$ of the variance in DOC concentrations, far more, typically 60 to $70 \%$, is driven by the rapid increases in the amount of new burns on deep peat occurring over the past 2 decades.

Historical reconstructions may suffer from unmeasured confounding variables leading to potential misinterpretation of results. During the period of the present study, most of England experienced a short-term drought (summer 1995) which was observed to result in a highly significant water table drawdown at an upland blanket peat catchment within approximately $140 \mathrm{~km}$ of the study sites used here (Moor House National Nature Reserve, North Pennines, UK, Evans et al. 1999). It is likely the 3 sites examined here experienced the same phenomenon. Such drawdown may alter peat structure, in particular porosity (Holden \& Burt 2002), and has been suggested may lead to increased DOC productivity (Tipping et al. 1999). However, Worrall et al. (2008) identified no trends in DOC flux resulting from this drought at Moor House where the drawdown observed by Evans et al. (1999) occurred, nor were they apparent at the larger scale (Worrall \& Burt 2008). The differing responses between burned and unburned catchments are shown in Fig. 7. All 3 catchments examined here (Broomhead is shown in Fig. 7 as an example) show a marked reduction in DOC export in response to this drought, followed by more pronounced elevated levels in the following $2 \mathrm{yr}$ compared to the unburned catchment. Also, the rise in DOC export continues after this transient anomaly, something not observed within the unburned catchment. That burning began to expand rapidly into blanket peat areas around 1995 (Fig. 8), and continued thereafter, suggests this is the more important driver of overall increased DOC export. However, a synergistic interaction between burning, which exposes the peat surface for a number of years, and drought should not be excluded.

The source of this measured increase in $\mathrm{hDOC}$ export is currently unclear. The primary source of hDOC (water colour assessed as Hazen, as in the present study) in peat catchments is the microbial decomposition of peat (McDonald et al. 1991, Mitchell \& McDonald 1992), suggesting that rising hDOC could result from increased decomposition of - and carbon loss from-underlying blanket peats. Such an interpretation is also implied by Yallop \& Clutterbuck (2009), who observed no increase in drainage $\mathrm{hDOC}$ where moorland burning occurred on thin-peat or mineral soils as would be expected if release of 'new' decay

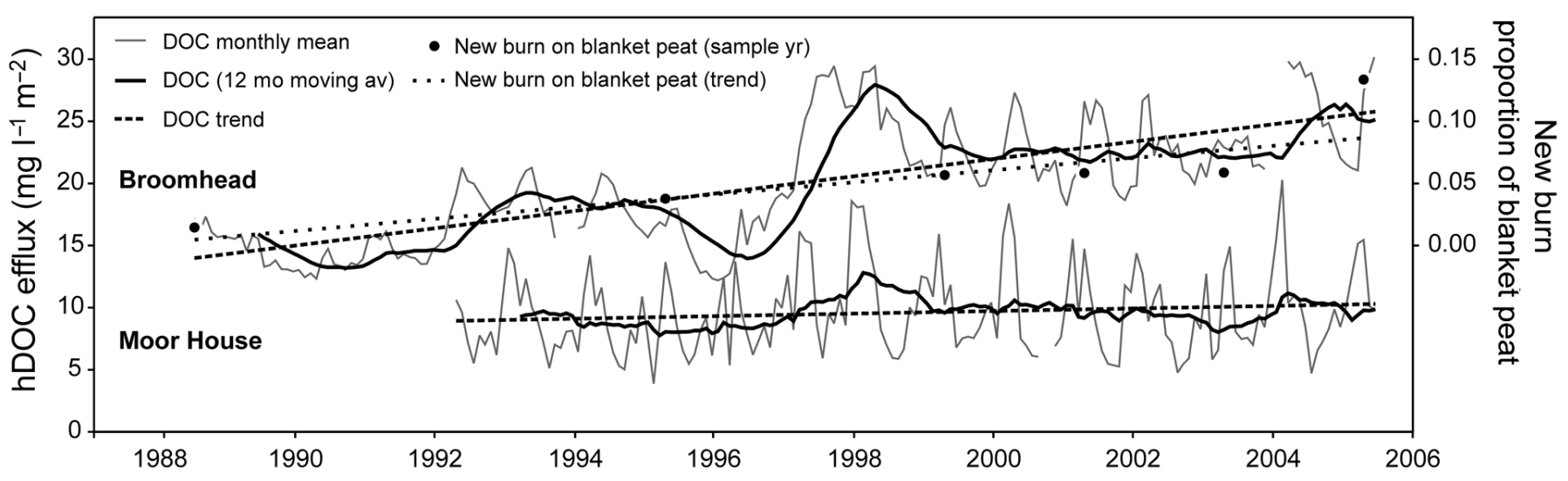

Fig. 7. Comparison of changes in humic dissolved organic carbon (hDOC) concentrations in a burned catchment (Broomhead: $42 \%$ blanket peat) and an essentially unburned catchment (Moor House: $97 \%$ blanket peat). A significant drought occurred in 1995 at the same time as management burning began to spread rapidly into areas of blanket peat in the Broomhead catchment (see Fig. 8). Only very small amounts of experimental burning takes place at Moor House; it is effectively a very rare example of an unburned ericaceous blanket peat catchment in England. Data for Moor House were sourced from the Environmental Change Network 

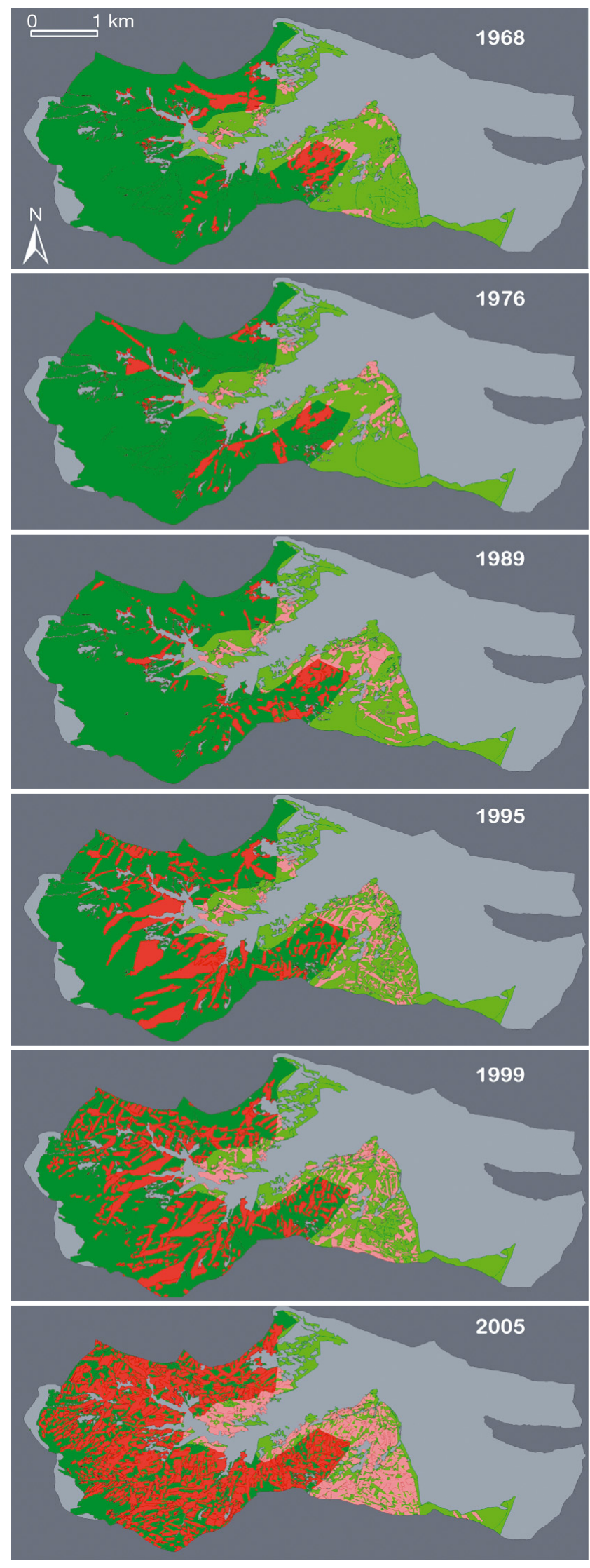

Fig. 8. Changes in the intensity of moorland burning on blanket peat and upland soils with peaty topsoils over nearly 4 decades, Broomhead, UK. Area of burn management can be seen moving progressively into blanket peat areas not in recent rotational burn programmes. This increase is not atypical in many parts of England where the amount of burning has doubled since 1970 (Yallop et al. 2006a). Greens: area of Calluna. reds: Class 1 \& 2 burns (see Section 2.5.3.); dark colours: blanket peat; light colours: peat-topped soils; light grey: non-Calluna vegetation

products were being observed as a result of burning. Instead, the phenomenon of elevated $\mathrm{hDOC}$ export only occurs as a consequence of burning on blanket peat. Drainage from upland peat-dominated catchments that contain no areas of extensive burning, and have not exhibited such rapid increases in drainage DOC levels, has been observed to contain primarily young carbon with a mean age of only $5 \mathrm{yr}$ (Moor House; Tipping et al. 2010). The increased hDOC efflux observed here, in heavily burned catchments that have seen a near doubling in drainage hDOC (at the catchment scale), might suggest changes in hydrological pathways and increased microbial mobilisation of older carbon stores. However, until the components of the $\mathrm{hDOC}$ in drainage from such sites are more fully characterised, or dated, the actual source of this observed increase in $\mathrm{hDOC}$ export remains uncertain.

The estimates of carbon efflux as hDOC from blanket peat in the 3 South Pennine catchments examined here (9.4 to $29.3 \mathrm{~g} \mathrm{~m}^{-2} \mathrm{yr}^{-1}$ ) are consistent with DOC exports determined from areas of peat or peat-dominated catchments in a number of other studies (Table 6). It can be seen that for 1976, some 9.4 to $11.8 \mathrm{~g} \mathrm{~m}^{-2} \mathrm{yr}^{-1}$ were exported from the studied catchments as hDOC, concordant with the range of other estimates in the UK. However, for the period 1990-2005 these figures almost trebled (27.7 to $29.3 \mathrm{~g} \mathrm{~m}^{-2} \mathrm{yr}^{-1}$ ) and are now consistent with higher estimates from some upland peat catchments in Scotland (up to $26.2 \mathrm{~g} \mathrm{~m}^{-2} \mathrm{yr}^{-1}$ ) and the North Pennines (up to $23.7 \mathrm{~g} \mathrm{~m}^{-2} \mathrm{yr}^{-1}$ ). It may be worth noting that the highest fluxes estimated in the UK in other studies (Table 6) were determined for Scottish upland peat catchments that are managed for red grouse (Dawson et al. 2002) and rivers draining areas of the North Pennine AONB (Worrall et al. 2008), where over $20 \%$ of the area of blanket peat shows evidence of recent burning (Yallop et al. 2006b). It can be estimated from the results presented here that a given area of blanket peat exposed by new management burns produces 5 to 15 times the hDOC export than fully canopied areas. The use of fire to manage grouse moor is not a minor activity in England, and the area of new burn has doubled between 1970 and 2000 to over $114 \mathrm{~km}^{2} \mathrm{yr}^{-1}$ (Yallop et al. 2006a). The increase in the use of fire to manage grouse moor, especially on blan- 
Table 6. Changes in carbon export for South Pennine study sites (italics; DOC flux scaled to area of blanket peat) compared to a series of other peat and peat-dominated catchments. DOC: dissolved organic carbon

\begin{tabular}{|c|c|c|c|}
\hline Study catchment (peat coverage, \%) & $\begin{array}{l}\text { DOC efflux } \\
\left(\mathrm{g} \mathrm{m}^{-2} \mathrm{yr}^{-1}\right)\end{array}$ & Study period & Source \\
\hline \multicolumn{4}{|l|}{ Scotland } \\
\hline Scottish highlands (peat-dominated) & $7.0-10.3$ & 1993 & Hope et al. (1997) \\
\hline Brocky Burn upper (67) & $17.4-21.4$ & 1996-1998 & Dawson et al. (2008) \\
\hline Water of Charr (81) & $16.9-26.2$ & $1996-1998$ & Dawson et al. (2008) \\
\hline \multicolumn{4}{|l|}{ England } \\
\hline Rivers Tees and Coquet, North Pennines & $3.6-23.7$ & $1970-2005$ & Worrall et al. (2008) \\
\hline South Pennines 1976 (100) & $9.4-11.8$ & 1976 & Present study \\
\hline Great Dunn Fell, North Pennines (ca. 100) & $7.0-15.0$ & $1992-1996$ & Scott et al. (1998) \\
\hline Moor House, North Pennines (97) & $9.4-15.0$ & 1999 & Worrall et al. (2003a) \\
\hline Upper North Grain, Peak District (100) & 15.4 & $2005-2006$ & Pawson et al. (2008) \\
\hline South Pennines 2000s (100) & $27.7-29.3$ & $2000-2005$ & Present study \\
\hline \multicolumn{4}{|l|}{ Wales } \\
\hline Upper Hafren, Mid-Wales (peat-dominated) & 8.4 & $1996-1998$ & Dawson et al. (2002) \\
\hline \multicolumn{4}{|l|}{ Northern Europe } \\
\hline Salmisuro mire complex, Finland (79) & $4.2-11.3$ & $2006-2007$ & Jager et al. (2009) \\
\hline \multicolumn{4}{|l|}{ USA } \\
\hline Peatlands, Minnesota (100) & 8.9-27.6 (lowland bog) & $1981-1985$ & Urban et al. (1989) \\
\hline \multicolumn{4}{|l|}{ Canada } \\
\hline Mer Bleue Bog, Ontario (100) & 8.3 & 1998-1999 & Fraser et al. (2001) \\
\hline Bois-des-Bel peatland, Quebec (100) & $3.5-4.8$ (restored) & $1999-2001$ & Waddington et al. (2008) \\
\hline Bois-des-Bel peatland, Quebec (100) & $6.2-10.3$ (cutover) & 1999-2001 & Waddington et al. (2008) \\
\hline
\end{tabular}

ket peat, over this period in the examined catchments is striking and is illustrated by the burn maps for Broomhead shown in Fig. 8. Concerns as to the potential negative effects on biodiversity of such intensive fire use have been raised previously (see Tucker 2003, Yallop et al. 2009 for review). The results presented here add concerns about the possible negative impact of carbon budgets where this burning occurs on deep peat.

As data for other fluvial or gaseous carbon fluxes for the 3 study catchments were not available, there is no evidence of how moorland burn management might affect these aspects of the carbon budgets. However, such moorland burning has been identified as causing increased peat erosion (Imeson 1971), a process resulting from both exposure of bare peat surface (Yeloff et al. 2006) and freeze-thaw effects (Maltby et al. 1990). Such enhanced erosion will contribute to carbon efflux as POC, to be added to the hDOC effects observed here. We are unaware of comparative $\mathrm{CO}_{2}$ flux measurements between areas of exposed peat arising from new burning and natural bog; however, Ward et al. (2007) showed $40 \%$ increased microbially mediated gross $\mathrm{CO}_{2}$ efflux related to changes in vegetation structure in older burns, suggesting changes to this aspect of carbon budgets are also possible. The use of complete carbon budget calculations for the unburned, but otherwise similar, upland blanket peat catchment at Moor House (Worrall et al. 2003a) allows assessment of the relative importance of other aspects of carbon flux and the possibility of a speculative reconstruction. Assuming burning has no adverse, or positive, affects on other aspects of carbon flux budgets, transposition of the values produced by Worrall et al. (2003a) to our study catchments, but with substitution of the observed changes in carbon export as hDOC estimated for Agden, Broomhead and Langsett catchments in the South Pennines, suggests that these 3 catchments moved from being net carbon sinks in the 1970s to net sources post year 2000. This observation is not offered as empirical evidence of such a change occurring, but to provide a context for the potential importance of the scale of change in export observed.

The rapidity with which the observed increased hDOC efflux could be cycled back to the atmosphere as $\mathrm{CO}_{2}$, with any potential influence on climatic warming, is not certain. However, DOC is ultimately mineralised, with a fairly short half-life estimated at $7.1 \mathrm{yr}$ (Hansell et al. 2004) or 5 to 15 yr (Keiber et al. 1990), which suggests that the observed rise in carbon efflux from catchments managed in this way does provide another potential source of $\mathrm{CO}_{2}$ emission. However, the failure to observe a significant relationship between temperature and hDOC release here indicates that any putative positive feedback loops between climate warming and soil carbon, at least from the examined blanket peat reservoir, are not yet clear. Instead, localised land-use changes are a far more important driver of carbon export. 


\section{CONCLUSIONS}

The modelled hDOC flux data presented here indicate that some blanket peats in South Pennine catchments, where they are currently managed as grouse moors, may be exporting carbon in the form of $\mathrm{hDOC}$ at rates of up to 27 to $29 \mathrm{~g} \mathrm{~m}^{-2} \mathrm{yr}^{-1}$. Significantly smaller rates of export have been estimated for other South Pennine catchments not undergoing burn management (15 $\mathrm{g} \mathrm{m}^{-2} \mathrm{yr}^{-1}$; Pawson et al. 2008). Controlled burning results in a 5- to 15 -fold increase in the humic carbon export as DOC from blanket peat compared to equivalent unmanaged areas in this part of the UK. This increase in fluvial hDOC efflux suggests that much of the increasing DOC concentrations noted over the recent decades, where drainage is from blanket peat catchments, are not merely a result of changes in rainfall or discharge, but arise partly as a result of the observed increases in fire usage on blanket peat.

Acknowledgements. Some of the work reported here was supported by Yorkshire Water Services Limited and we thank them. We also acknowledge use of data provided from the Environmental Change Network for Fig. 7. The project required access to many areas, and the help of numerous landowners, gamekeepers and graziers is gratefully acknowledged.

\section{LITERATURE CITED}

Aiken GW, McKnight DM, Wershaw RL, MacCarthy P (1985) An introduction to humic substances in soil, sediment and water. In: Aiken GW, McKnight DM, Wershaw RL, MacCarthy P (eds) Humic substances in soil, sediment and water. Wiley, New York, NY, p 1-9

Aitkenhead JA, Hope D, Billett MF (1999) The relationship between dissolved organic carbon in stream water and soil organic carbon pools at different spatial scales. Hydrol Process 13:1289-1302

Avery BW (1980) Soil classification in England and Wales: higher categories. Soil Survey Technical Monograph No. 14, Soil Survey of England and Wales, Harpenden

Batjes NH (1996) Total carbon and nitrogen in the soils of the world. Eur J Soil Sci 47:151-163

Billett MF, Palmer SM, Hope D, Deacon CM and others (2004) Linking land-atmosphere-stream carbon fluxes in a lowland peatland system. Global Biogeochem Cycles 18: GB1024. doi:10.1029/2003GB002058

Buckingham S, Tipping E, Hamilton-Taylor J (2008) Concentrations and fluxes of dissolved organic carbon in UK topsoils. Sci Total Environ 407:460-470

Clutterbuck B, Yallop AR (in press) Land management as a factor controlling dissolved organic carbon release from upland peat soils 2: Changes in DOC productivity over four decades. Sci Total Environ

Cox PM, Betts RA, Jones CD, Spall SA, Totterdell IJ (2000) Acceleration of global warming due to carbon-cycle feedbacks in a coupled climate model. Nature 408: $184-187$

Dawson JJC, Smith P (2007) Carbon losses from soil and its consequences for land-use management. Sci Total Environ 382:165-190
Dawson JJC, Billett MF, Neal C, Hill S (2002) A comparison of particulate, dissolved and gaseous carbon in two contrasting upland streams in the UK. J Hydrol 257:226-246

> Dawson JJC, Soulsby C, Tetzlaff D, Hrachowitz M, Dunn SM, Malcolm IA (2008) Influence of hydrology and seasonality on DOC exports from three contrasting upland catchments. Biogeochemistry 90:93-113

Eatherall A, Naden PS, Cooper DM (1998) Simulating carbon flux to the estuary: the first step. Sci Total Environ 210/211:519-533

> Eatherall A, Warwick MS, Tolchard S (2000) Identifying sources of dissolved organic carbon on the River Swale, Yorkshire. Sci Total Environ 251/252:173-190

> Evans MG, Burt TP, Holden J, Adamson JK (1999) Runoff generation and water table fluctuations in blanket peat: evidence from UK data spanning the dry summer of 1995. J Hydrol 221:141-160

Evans CD, Monteith DT, Cooper DM (2005) Long-term increases in surface water dissolved organic carbon: observations, possible causes and environmental impacts. Environ Pollut 137:55-71

Fowler J, Cohen L (1990) Practical statistics for field biology. Open University Press, Milton Keynes

Fraser CJD, Roulet NT, Moore TR (2001) Hydrology and dissolved organic carbon biogeochemistry in an ombrotrophic bog. Hydrol Process 15:3151-3166

Grieve IC (1984) Concentrations and annual loading of dissolved organic matter in a small moorland stream. Freshw Biol 14:533-537

> Hansell DA, Kadko D, Bates NR (2004) Degradation of terrigenous dissolved organic carbon in the western Arctic Ocean. Science 304:858-861

Hirsch RM, Slack JR, Smith RA (1982) Techniques of trend analysis for monthly water quality data. Water Resour Res 18:107-121

Holden J, Adamson JK (2002) The Moor House long-term upland temperature record: new evidence of recent warming. Weather 57:119-127

> Holden J, Burt TP (2002) Laboratory experiments on drought and runoff in blanket peat. Eur J Soil Sci 53:675-689

> Hope D, Billett MF, Cresser MS (1994) A review of the export of carbon in river water: fluxes and processes. Environ Pollut 84:301-324

Hope D, Billett MF, Milne R, Brown TAW (1997) Exports of organic carbon in British rivers. Hydrol Process 11: $325-344$

> Imeson AC (1971) Heather burning and soil erosion on the North Yorkshire moors. J Appl Ecol 8:537-542

Jager DF, Wilmking M, Kukkonen JVK (2009) The influence of summer seasonal extremes on dissolved organic carbon export from a boreal peatland catchment: evidence from one dry and one wet growing season. Sci Total Environ 407:1373-1382

Jenkinson DS, Adams DE, Wild A (1991) Model estimates of $\mathrm{CO}_{2}$ emissions from soil in response to global warming. Nature 351:304-306

Kerekes J, Beauchamp S, Tordon R, Tremblay C, Pollock T (1986) Organic versus anthropogenic acidity in tributaries of the Kejimkujik watersheds in western Nova Scotia. Water Air Soil Pollut 31:165-179

> Keiber RJ, Zhou X, Mopper K (1990) Formation of carbonyl compounds from UV-induced photodegradation of humic substances in natural waters: fate of riverine carbon in the sea. Limnol Oceanogr 35:1503-1515

Kokkonen TS, Jakeman AJ, Young PC, Koivusalo HJ (2003) Predicting daily flows in ungauged catchments: model regionalization from catchment descriptors at the Co- 
weeta Hydrologic Laboratory, North Carolina. Hydrol Process 17:2219-2238

Mackney D, Hodgson JM, Hollis JM, Staines SJ (1983) Legend for the 1:250000 soil map of England and Wales. Soil Survey of England and Wales, Harpenden

Maidment DR (2002) Arc Hydro: GIS for water resources. ESRI Press, Redlands, CA

Maltby E, Legg CJ, Proctor MCF (1990) The ecology of severe moorland fire on the North York moors: effects of the 1976 fires, and subsequent surface and vegetation development. J Ecol 78:490-518

Martikainen PJ, Nykänen H, Alm J, Silvola J (1995) Change in fluxes of carbon dioxide, methane and nitrous oxide due to forest drainage of mire sites of different trophy. Plant Soil 168/169:571-577

McDonald AT, Mitchell GN, Naden PS, Martin DSJ (1991) Discoloured water investigations. Report to Yorkshire Water, University of Leeds

Meybeck M (1993) Riverine transport of atmospheric carbon sources, global typology and budget. Water Air Soil Pollut 70:443-463

Milne R, Brown TAW (1997) Carbon in the vegetation and soils of Great Britain. J Environ Manage 49:413-433

Mitchell G, McDonald AT (1992) Discolouration of water by peat following induced drought and rainfall simulation. Water Res 26:321-326

Oke TR (1982) The energetic basis of the urban heat island. Q J R Meteorol Soc 108:1-24

Palmer SM, Hope D, Billett MF, Dawson JJC, Bryant CL (2001) Sources of organic and inorganic carbon in a headwater stream: evidence from carbon isotope studies. Biogeochemistry 52:321-338

Pastor J, Solin J, Bridgham SD, Updegraff K, Harth C, Weishampel P, Dewey B (2003) Global warming and the export of dissolved organic carbon from boreal peatlands. Oikos 100:380-386

Pawson RR, Lord DR, Evans MG, Allott TEH (2008) Fluvial organic carbon flux from an eroding peatland catchment, southern Pennines, UK. Hydrol Earth Syst Sci 12: 625-634

Roehm CL, Roulet NT (2003) Seasonal contribution of $\mathrm{CO}_{2}$ fluxes in the annual $\mathrm{C}$ budget of a northern bog. Global Biogeochem Cycles 17:1029 doi:10.1029/2002GB001889

Scott MJ, Jones MN, Woof C, Tipping E (1998) Concentrations and fluxes of dissolved organic carbon in drainage water from an upland peat system. Environ Int 24:537-546

Sefton CEM, Howarth SM (1998) Relationships between dynamic response characteristics and physical descriptors of catchments in England and Wales. J Hydrol 211:1-16

Shepard D (1968) A two-dimensional interpolation function for irregularly spaced data. Proceedings of the 23rd National Conference of the Association for Computing Machinery, New York, NY, p 517-524

Smith TM, Shugart HH (1993) The transient response of terrestrial carbon storage to a perturbed climate. Nature 361:523-526

Tipping E, Woof C, Rigg E, Harrison AF and others (1999) Climatic influences on the leaching of dissolved organic matter from upland UK moorland soils, investigated by a field manipulation experiment. Environ Int 25:83-95

Tipping E, Marker AFH, Butterwick C, Collett GD and others (1997) Organic carbon in the Humber rivers. Sci Total Environ 194/195:345-355

Tipping E, Billett MF, Bryant CL, Buckingham S, Thacker SA (2010) Sources and ages of dissolved organic matter in peatland streams: evidence from chemistry mixture modelling and radiocarbon data. Biogeochemistry (in press) doi:10.1007/s10533-010-9409-6

> Tranvik LJ, Jansson M (2002) Terrestrial export of organic carbon. Nature 415:861-862

Trumbore SE, Chadwick OA, Amundson R (1996) Rapid exchange between soil carbon and atmospheric carbon dioxide driven by temperature change. Science 272: 393-396

Tucker G (2003) Review of the impacts of heather and grassland burning in the uplands on soils, hydrology and biodiversity. Research Report No. 550, English Nature, Peterborough

Urban NR, Bayley SE, Eisenreich SJ (1989) Export of dissolved organic carbon and acidity from peatlands. Water Resour Res 25:1619-1628

Waddington JM, Tóth K, Bourbonniere R (2008) Dissolved organic carbon export from a cutover and restored peatland. Hydrol Process 22:2215-2224

> Ward SE, Bardgett RD, McNamara NP, Adamson JK, Ostle NJ (2007) Long-term consequences of grazing and burning on northern peatland carbon dynamics. Ecosystems 10: $1069-1083$

Watts CD, Naden PS, Machall J, Banks J (2001) Long term variation in water colour from Yorkshire catchments. Sci Total Environ 278:57-72

Worrall F, Burt TP (2008) The effect of severe drought on the dissolved organic carbon (DOC) concentration and flux from British rivers. J Hydrol 361:262-274

- Worrall F, Reed M, Warburton J, Burt T (2003a) Carbon budget for a British upland peat catchment. Sci Total Environ 312:133-146

Worrall F, Burt T, Shedden R (2003b) Long term records of riverine dissolved organic matter. Biogeochemistry 64: 165-178

- Worrall F, Harriman R, Evans CD, Watts C and others (2004) Trends in dissolved organic carbon in UK rivers and lakes. Biogeochemistry 70:369-402

> Worrall F, Burt T, Adamson JK (2008) Long-term records of dissolved organic carbon flux from peat-covered catchments: evidence for a drought effect? Hydrol Process 22: 3181-3193

> Yallop AR, Clutterbuck B (2009) Land management as a factor controlling dissolved organic carbon release from upland peat soils. 1. Spatial variation in DOC productivity. Sci Total Environ 407:3803-3813

> Yallop AR, Thacker JI, Thomas G, Stephens M, Clutterbuck B, Brewer T, Sannier CAD (2006a) The extent and intensity of management burning in the English uplands. J Appl Ecol 43:1138-1148

Yallop AR, Thacker JI, Clutterbuck B (2006b) Mapping extent of burn management in the North Pennines: review of extent year 2001-2003. Research Report No. 698, English Nature, Peterborough

Yallop AR, White SM, Clutterbuck B (2008) Evidence for a mechanism driving recent observed trends in dissolved organic carbon release from upland peat soils. Asp Appl Biol 85:127-132

Yallop A, Thacker J, Clutterbuck B (2009) Burning issues. The history and ecology of managed fires in the uplands. In: Bonn A, Allott T, Hubacek K, Stewart J (eds) Drivers of environmental change in uplands. Routledge, Abingdon, p 171-185

Yeloff DE, Labadz JC, Hunt CO (2006) Causes of degradation and erosion of a blanket mire in the southern Pennines, UK. Mires Peat 1:1-18 